DOI: https://doi.org/10.24127/ajpm.v10i4.3875

\title{
THE DEVELOPMENT OF TOONDOO ONLINE COMIC BASED ON RME TO SUPPORT STUDENT'S MATHEMATICAL LITERACY SKILLS
}

\author{
Rohati $^{1 *}$, Ade Kumalasari ${ }^{2}$, Marlina ${ }^{3}$, Naya Junia ${ }^{4}$ \\ 1,2,3,4 Pendidikan Matematika Universitas Jambi, Kota Jambi, Indonesia \\ *Corresponding author. Perumahan Griya Sentosa IV Blok B Nomor 18, 36129, Kota Jambi, Indonesia \\ E-mail: $\quad$ rohati.fkip@unja.ac.id $\left.{ }^{*}\right)$ \\ ade.kumalasari@unja.ac.id ${ }^{2}$ \\ marlina@unja.ac.id ${ }^{3}$ \\ $\underline{\text { nayajunia97@gmail.com }}^{4)}$
}

Received 28 June 2021; Received in revised form 12 September 2021; Accepted 02 October 2021

\begin{abstract}
This research aims at 1) Developing a valid, practical, and effective Toondoo online comic media based on realistic math education (RME) on relations and functions material in junior high school, 2) Knowing whether RME- based Toondoo online comics can improve mathematical literacy skills. The research type is research and development with the ADDIE development model but the implementation stage is not carried out. The population of this research was all eighth grade students of SMPN 7 Jambi. Grade VIII $\mathrm{H}$ was taken as the sample of Toondoo online comic research. Response questionnaire and test are the data instruments for a validity, practicality and effectiveness of research. Post-test after learning Toondoo online comic is used as the instrument for mathematical literacy skills. Based on data analysis, the average validation of material, media and design experts falls into the very valid category. The results of the practicality of Toondoo online comic media based on RME are practical, making it worth testing in the learning process. The results of the learning test state that students' average value is 85.88 and mastery learning is $94.12 \%$. The results of post-test students' mathematical literacy skills state that the average class is at level 3 and above with a percentage of $91.17 \%$ which is very good criteria. Based on student learning outcomes and post-test, online comic media based on RME is effective to be used in learning process in order to improve students' mathematical literacy skills.
\end{abstract}

Keywords: Comics; Mathematical literacy; RME; Toondoo

\begin{abstract}
Abstrak
Penelitian ini bertujuan untuk 1) Mengembangkan media komik online Toondoo yang valid, praktis, dan efektif berbasis pendidikan matematika realistik (RME) pada materi relasi dan fungsi di SMP, 2) Mengetahui apakah komik online Toondoo berbasis RME dapat meningkatkan keterampilan literasi matematika. Jenis penelitiannya adalah penelitian dan pengembangan dengan model pengembangan ADDIE namun tahap implementasi tidak dilakukan. Populasi dalam penelitian ini adalah seluruh siswa kelas VIII SMPN 7 Jambi. Kelas VIII H diambil sebagai sampel penelitian komik online Toondoo. Kuesioner respon dan tes merupakan instrumen data untuk validitas, kepraktisan dan keefektifan penelitian. Post-test setelah pembelajaran komik online Toondoo digunakan sebagai instrumen keterampilan literasi matematika. Berdasarkan analisis data, rata-rata validasi ahli materi, media dan desain masuk dalam kategori sangat valid. Hasil kepraktisan media komik online Toondoo berbasis RME bersifat praktis sehingga layak untuk diujicobakan dalam proses pembelajaran. Hasil tes belajar menyatakan bahwa nilai rata-rata siswa 85,88 dan ketuntasan belajar 94,12\%. Hasil post-test kemampuan literasi matematika siswa menyatakan bahwa rata-rata kelas berada pada level 3 ke atas dengan persentase 91,17\% dengan kriteria sangat baik. Berdasarkan hasil belajar siswa dan post-test, media komik online berbasis RME efektif digunakan dalam proses pembelajaran dalam rangka meningkatkan kemampuan literasi matematika siswa.
\end{abstract}

Kata kunci: Komik; Literasi matematika; RME; Toondoo

This is an open access article under the Creative Commons Attribution 4.0 International License 
DOI: https://doi.org/10.24127/ajpm.v10i4.3875

\section{INTRODUCTION}

Mathematical literacy is defined as knowledge to know and apply the basic mathematics in our everyday living to solve problems and be able to explain to others how to use mathematics (Abidin, 2017; Ojose, 2011). According to Mahdiansyah (2014), literacy learning is characterized by $3 \mathrm{R}$ namely responding, revising, and reflecting. At the responding stage, students respond to assignments or texts that they read. The teacher responds to students' answer in order to achieve what is expected. Revising includes various language activities, for example revisions can be carried out at the level of the formulation of ideas. Reflecting is an evaluation of what has been done and what has been seen when the learning process is carried out.

Literacy is important because it is defined as the ability to use written information in accordance with situations encountered in everyday life. However, based on the 2018 PISA survey, Indonesia's mathematical literacy achievement was ranked 72 out of 78 countries with a score of 379 out of an average score of 489 . Based on the results of these scores, Indonesia is still at level 1(OECD, 2019).

One of the purposes of mathematics education is a practical purpose that denotes the importance of developing mathematics learning using real context in solving everyday problems (Widjaja, 2013; Wijaya, 2012; Yuanita, Zulnaidi, \& Zakaria, 2018). Mathematics is a human activity, and students use actual circumstances to build informal context-specific solution method (Julie \& Gierdien, 2020; Peck, 2018; Theodora \& Hidayat, 2018). Environment and all forms of conditioned activity aims to increase knowledge, change attitudes or instill skills for everyone who takes advantage of it (Sanjaya, 2014). However, in the learning process usually there is still a lack of media utilization as a tool to deliver mathematics learning material. In an observation it was found that teacher tends to give the concept of mathematics at first without any activity that involve students' cognitive related to daily basis in order to acquire their knowledge. Students will get used to receive material without experiencing the process of constructing knowledge at all, even worse, students are reluctant to read learning resources and learning process is only for short term in their minds not to be used as meaningful learning.

As for the causes of not using the media as a tool to build students' knowledge are the lack of attention by the teacher towards the media needs for some mathematics subject matter, inability to develop a suitable media in the learning process, not using the real context for students related to daily life so it does not involve students in constructing knowledge directly, and do not take advantage of the advancement of technology in the world of education to the fullest, especially mathematics where it is needed a way to make abstraction becomes more concrete for students. Integration can be done by using learning media as a distribution of information based on realistic math education.

Visual media can accelerate the understanding and strengthen memory (Arsyad, 2014). One of the media that can be used with these criteria is a mathematical comic media. Learning using comics helps to engage students and shape student attitudes in a positive way (Affeldt, Meinhart, \& Eilks, 2018; Matuk, Hurwich, Spiegel, \& Diamond, 2021; Spiegel, McQuillan, Halpin, 
Matuk, \& Diamond, 2013) and motivation (Mercat, Vennebush, Budd, Simões, \& Struckmeier, 2017). According to Febrianto, Kamid, \& Rohati (2015), and Rohati, Winarni, \& Hidayat (2018) comics are a form of visual communication media that has the power to convey information in a popular and understandable way. It is because the interaction between text and images in comics combines the two components into a story that helps the production of coherence and context of information in science.

Developing comic media in mathematics is not easy because not all teachers can design cartoon animations like a comic cartoon artist. Toondoo evidently becomes a valuable feature of the technology for students who are not very good at drawing their ideas with paper and pen (González \& Milena, 2016). Pointed out that along with the development of technology in the 20s, its use can be used in making real math education-based comics with applications that have been provided by online-based technology. So students can directly access the comics that have been created through the web. The intended application is Toondoo. Printina (2017) says that users can create and compile learning materials in the form of comics. Toondoo are examples of online comic creation applications. Toondoo animated image templates provided by the application and also can be created by uploading photos (Wilujeng, 2015). Toondoo can be used by teachers to deliver learning material in the classroom, to demonstrate concepts visually, and to create a more pleasant learning atmosphere (Widyastuti, Rasiman, \& Setyowati, 2016).

According to Sumantri (2015), realistic math education (RME) which is meant in this case is school mathematics which is carried out by placing student's reality and experience as a starting point for learning. According to (Widari, Putra, \& Suwijaya (2013), in this realistic mathematics learning or PMR approach, students are given their own opportunity to find ideas and concepts, which in this concept begins with a realistic problem. According to Treffers, characteristics of the use of comics based on realistic math education are 1) the use of context, 2) the use of models for progressive mathematics, 3) the use of student construction results, 4) interactivity, and 5) the interrelationship can be utilized as a facility to improve students' mathematical literacy skills (Wijaya, 2012). According to Webb \& Peck (2020) the principles in RME are guided re-invention, progressive mathematization, didactical phenomenology and self developed models.

Based on the background description above, the objectives of this research are 1) to produce Toondoo online comic media that is based on realistic math education on relations and functions material in junior high schools which are valid, practical, and effective; 2) To find out whether Toondoo online comic based on realistic math education on relations and functions material in junior high school can improve mathematical literacy skills.

\section{METHOD}

The method used in Toondoo online comic research is research and development method. This method aims to produce products in the form of Toondoo online comic media and test the effectiveness of these products. While the model used in this research development is the ADDIE model 
(Analyze, Design, Development, Implement, and Evaluate). However, the implementation stage was not conducted because the researchers used media trials in only one class to see the effectiveness of the comic media.

This research was conducted at SMPN 7 Jambi, with consideration of the availability of resources owned by the school such as computer labs and internet networks that could be accessed well. The population in this study was all students of class VIII (eighth grader) semester 1 of SMPN 7 Jambi City consisting of classes of VIII A to VIII K with 367 students in total. The researchers use a cluster random sampling technique to select the sample so that 36 students from class VIII $\mathrm{H}$ is obtained as a sample of Toondoo online comic research. While 36 students from class VIII I is aimed to test the feasibility of the test results of learning achievement in order to obtain reliable test questions or the level of difficulty and different power with the test categories are appropriate to be used to determine student achievement test.

Data collection instruments that will be used in this development research is an instrument for the assessment of Toondoo online comic media and an instrument for assessment of mathematical literacy skills. Toondoo online comic assessment consists of a validation questionnaire, a practicality questionnaire and a test of the effectiveness of comic media. The validation questionnaire consisted of a validated questionnaire by material experts, media experts, and design experts. The practicality questionnaire consisted of a practicality questionnaire by individual trials, small group trials, and large group trials. Tests of learning achievement about effectiveness are obtained from large group trials after the use of the media in the learning process. While the assessment of mathematical literacy skills, examined from the process of answering questions in groups of the students after reading comics. The instrument is in the form of a mathematical literacy post-test question consisting of 6 items. The contexts of the question are in 6 types (levels 1-6) with different levels of difficulty. This instrument is intended to discover mathematical literacy skills after studying mathematics using Toondoo online comic.

Data obtained from the experts was analyzed to answer whether or not Toondoo online comic based on realistic math education in mathematics learning being developed is said to be valid examined from theoretical power. Meanwhile, data from individual observation with the subject matter teacher, small group and large group to find out the practicality of comic media, field observation is used to answer effectiveness criteria of comic media being developed. Data in the form of comments, suggestions, revisions, and observations during the trial process were analyzed descriptively qualitative and concluded as input to revise the product being developed. Meanwhile, data in the form of expert response scores, teacher assessment scores, student assessment scores and student learning outcomes were analyzed descriptively quantitatively.

The percentage criteria of validity used in this research development can be seen on the Table 1.

Table 1. Percentage criteria validity

\begin{tabular}{cc}
\hline Range of Percentage & Category \\
\hline $84<x \leq 100$ & Very valid \\
$68<x \leq 84$ & Valid \\
$52<x \leq 68$ & Quite valid \\
$36<x \leq 52$ & Invalid \\
$20 \leq x \leq 36$ & Very invalid \\
\hline
\end{tabular}


Comic media are said to be valid if they meet the criteria for the percentage of material validity, media validity, and design experts validity is quite valid, valid, or very valid.

The percentage criteria of practicality used in this research development are comic media that have very practical criteria (can be used without revision), are practical (without revision) and are quite practical (can be used but need to be revised slightly). This criteria can be seen on the Table 2 .

Table 2. Percentage criteria practicality

\begin{tabular}{cc}
\hline Range of Percentage & Category \\
\hline $84<x \leq 100$ & Very partical \\
$68<x \leq 84$ & Practical \\
$52<x \leq 68$ & Quite practical \\
$36<x \leq 52$ & Impractical \\
$20 \leq x \leq 36$ & Very impractical \\
\hline
\end{tabular}

The test of the effectiveness of comic media contains 20 questions item about relations and functions with a multiple-choice form that convenient to the question indicators with a certain score. The score is then converted to a scale value of $0-100$. From the scores that have been obtained, then the percentage of students who are completed is searched, referring to the KKM (Minimum Mastery Criteria) score of mathematics subject that is applied in SMPN 7 Jambi which is 75.

Student value data are converted into qualitative data using the following reference table (OECD, 2009). Mathematical literacy scores can be said to be complete, if students get a score with a minimum category "level 3 ".

The criteria of comic media is said to be effective if the percentage of the results of learning achievement test are between $61 \%-100 \%$ and students get a score with a minimum category "level 3".
Table 3. Criteria for assessment of mathematical literacy skills from OECD

\begin{tabular}{cc}
\hline Range of Scores & Category \\
\hline $669<x \leq 700$ & Level 6 \\
$607<x \leq 669$ & Level 5 \\
$544<x \leq 607$ & Level 4 \\
$482<x \leq 544$ & Level 3 \\
$420<x \leq 482$ & Level 2 \\
$358<x \leq 420$ & Level 1 \\
$0 \leq x \leq 358$ & Below Level 1 \\
\hline
\end{tabular}

\section{RESULT AND DISCUSSION}

Comic online construct with Toondoo consists of 18 chapters. Each chapter page contains several panels. Figure 1 shows the opening page of a comic chapter containing the chapter title, table of contents, and introduction to the characters in the chapter.
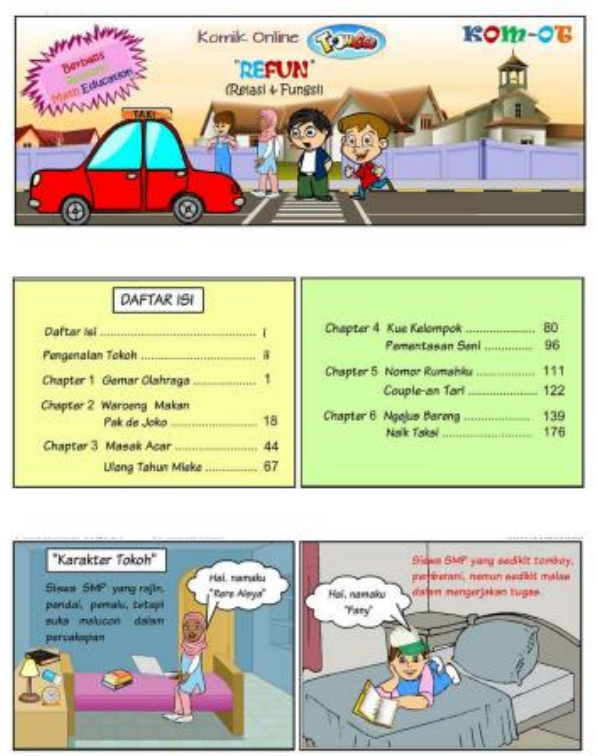

Figure 1. The opening page in Toondoo online comic

Figure 2 shows the embedding the concept in the chapter. Concept planting is presented in the form of dialogue between characters that flows naturally so as to build a familiar atmosphere for students. 

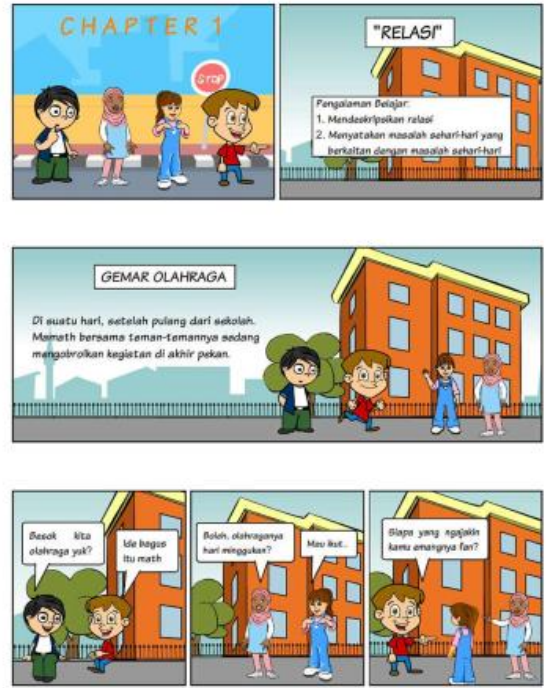

Figure 2. Embedding the concept in Toondoo online comic

Figure 3 shows a comic page display containing exercises. Each chapter in the developed comic is closed with exercises according to the concept of the material presented.
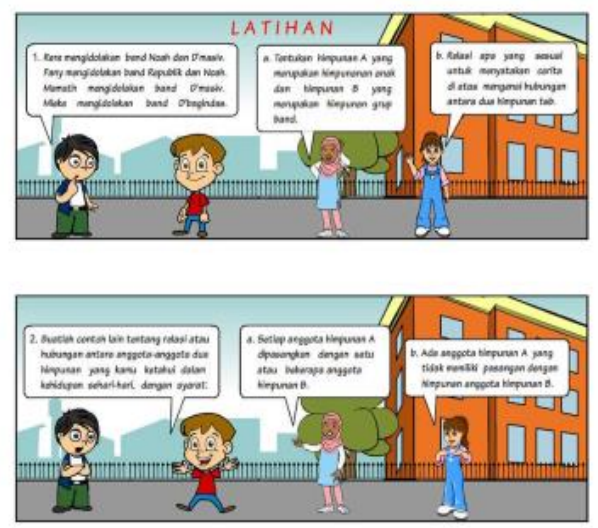

Figure 3. The exercise page in Toondoo online comic

\section{Characteristics of RME in Making Toondoo Online Comic}

At the stage of context use, realistic problems are used as a starting point in learning mathematics. Not only in the form of real problems, but these problems can be imagined by students' minds.
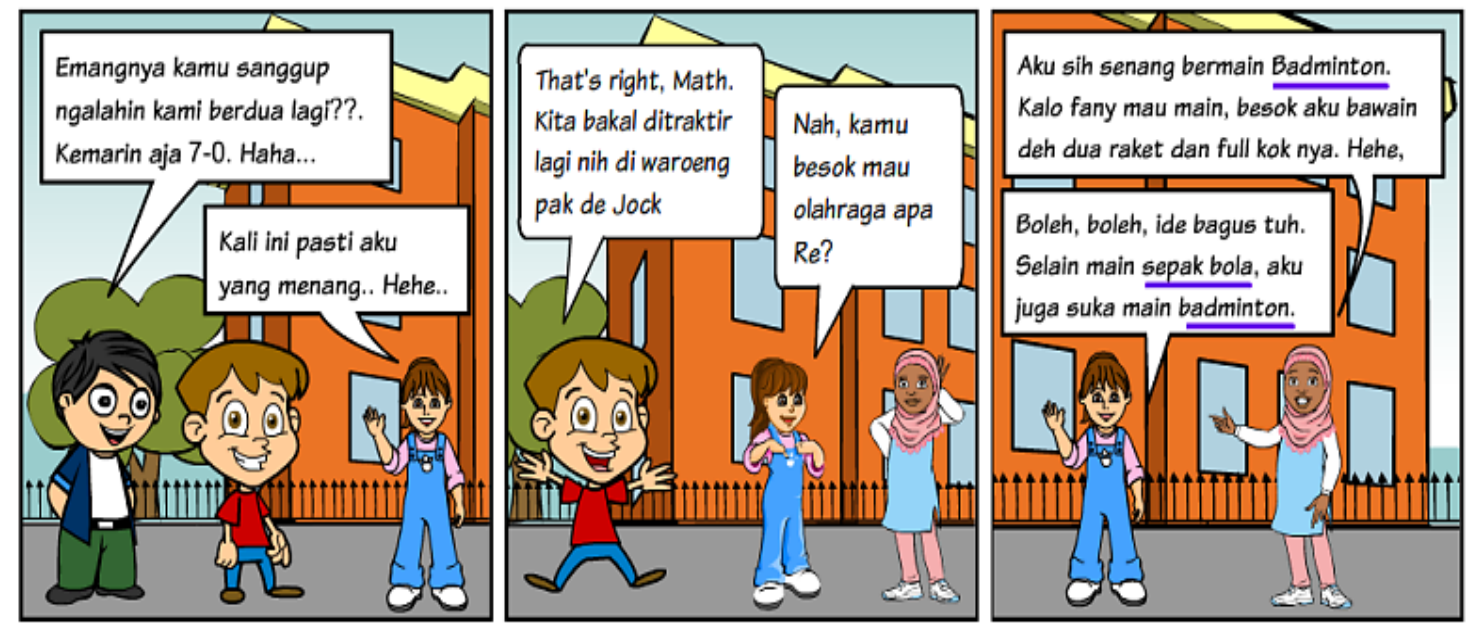

Figure 4. The use of context in Toondoo online comic

The Figure 4 shows that the problem to be faced is about "hobbies" of comic characters. In the next page, comic characters begin a dialog about hobbies from each of them.In their daily dialog, characters in the comic are raised through dialogue conversations about hobbies without ignoring the elements of the comic itself. The goal is to make the comic storyline look natural, as if the problem did occur in the students' environment. 
DOI: https://doi.org/10.24127/ajpm.v10i4.3875
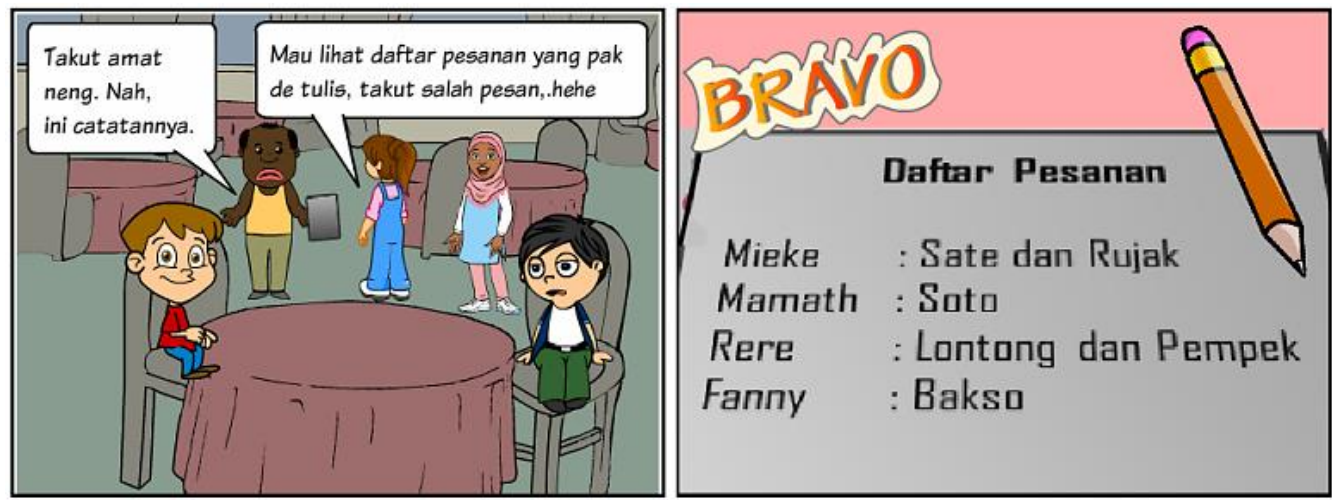

Figure 5. The use of progressive mathematical models in Toondoo online comic

After the use of the context at the beginning of comic dialog, the use of the model for progressive mathematical was also carried out. The use of a progressive mathematical model contains an explanation of the problem that has been presented in the context usage characteristics on the previous page. In order to help students to build knowledge, concepts and relate the problems which are still abstract to a more concrete thinking through a mathematical modeling. The use of the model for progressive mathematical can be seen on the Figure 5.

The third characteristic is contained in the organization of comic dialog based on realistic math education approach. It is because student construction results from student's cognition process towards the contexts and modeling in the previous conversation will be used at this stage. The characteristic can be seen on the Figure 6.
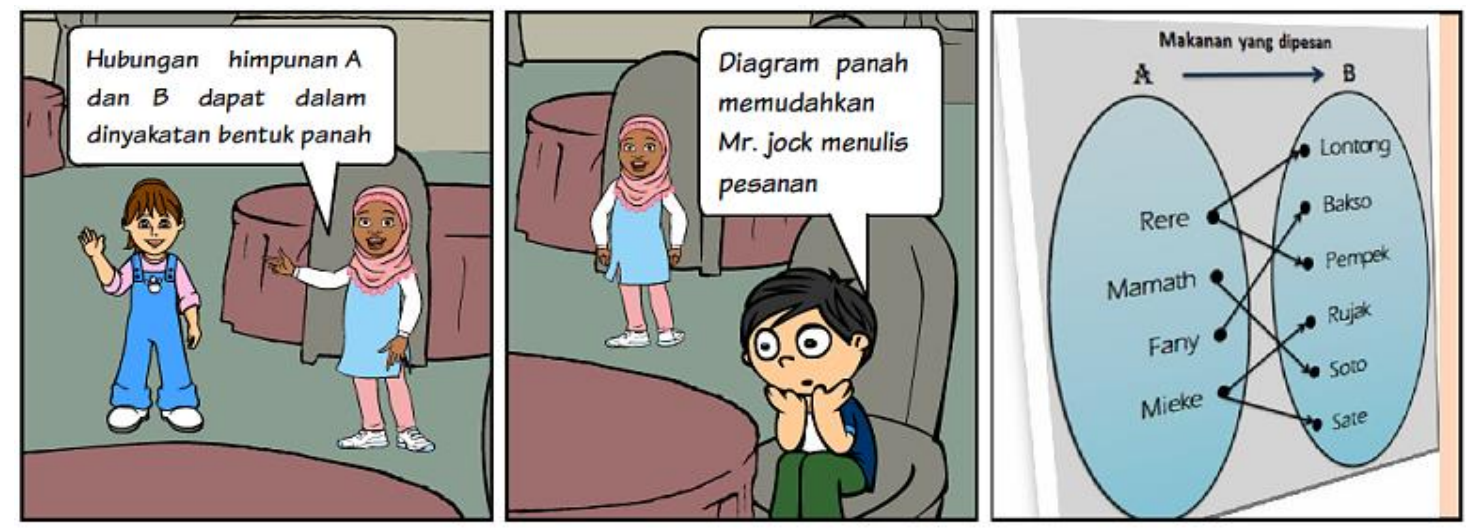

Figure 6. The utilization of student construction results in Toondoo online comic

The fourth characteristic of RME, interactivity, is presented through social processes done by the students in order to discover mathematical concept as shown on the Figure 7. They will communicate the results of cognition of thought to build the concept either like the dialog that occurs between comic characters or discussion. 

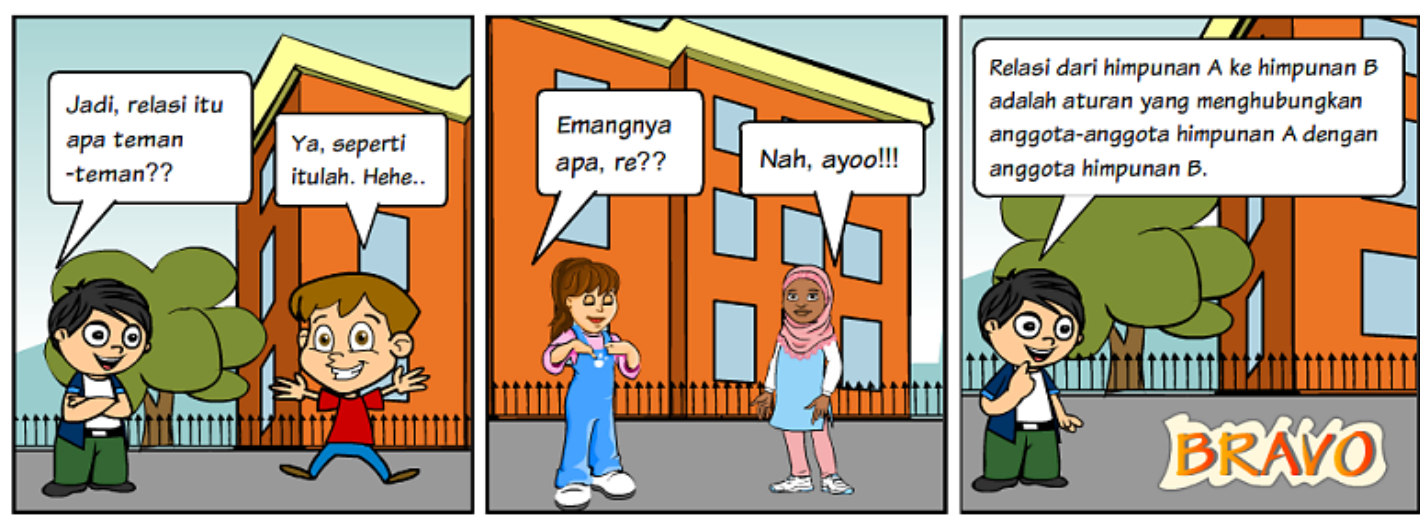

Figure 7. The utilization of interactivity in Toondoo online comic

The Figure 8 shows the interrelationship characteristic on RME. The use of the interrelationship shows that the mathematical concept cannot be separated from previous material or with other lessons. With the interrelationship pages of comics, students can build more than one mathematical concept simultaneously. In the text dialog it has been discussed that the material of relations and functions are closely related to previous mathematical concepts such as the concepts of sets and algebraic calculations. In addition, the relationship between relations and functions material is often associated with economic problems in everyday life.
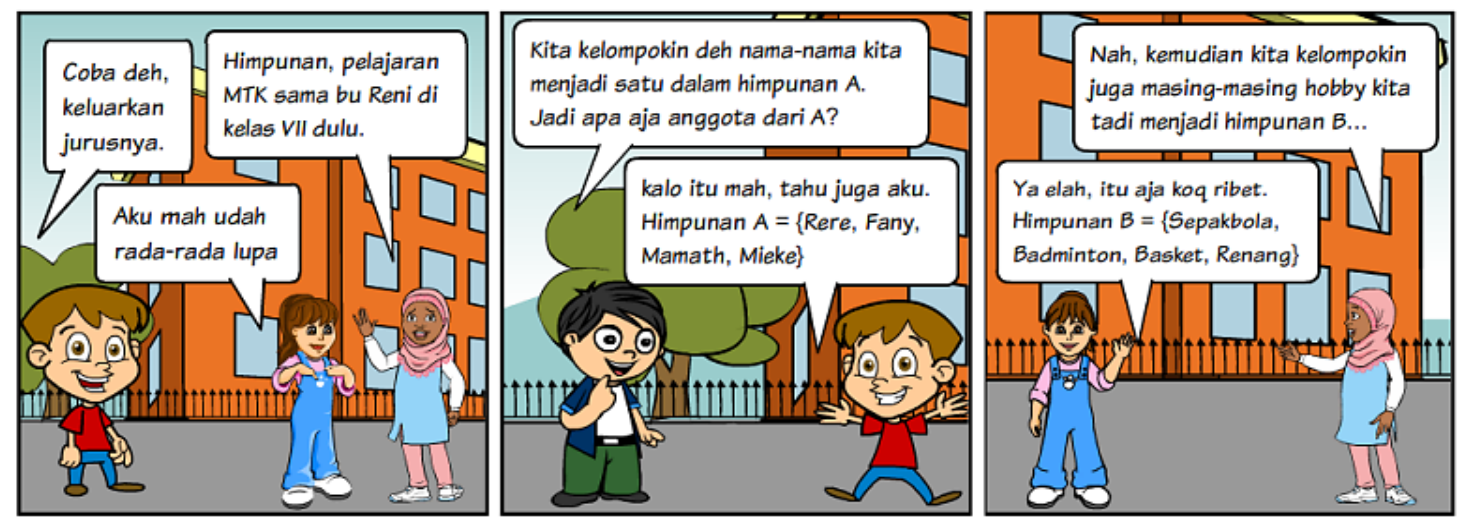

Figure 8. The use of interrelationship in Toondoo online comic

\section{Analysis of Validity Data}

The data of validity test for Toondoo online comic was obtained through respondent questionnaires given to material experts, design experts, and online comic media experts. Analysis of the questionnaire assessment by material experts consisted of four aspects, namely: 1) Accuracy of Content, 2) Accuracy of Content Coverage, 3) Digestibility, 4)
Language Use. The results of the validation and evaluation of comic media by material experts can be seen in the following Table 4.

In the next process, all aspects in the form of statements given to experts of the material are analyzed thoroughly. The data is obtained with $\Sigma$ (answer $\mathrm{x}$ weight of each choice) is $100, \Sigma$ (many items of questionnaire) is 25 with the highest weight is 5. Based on the 
calculation of the validity test that is the total score obtained from respondents divided by the ideal score of the assessment, it is known that the percentage of validity from experts' material is $80 \%$ with valid criteria.

Table 4. The assessment aspects of Toondoo online comic material experts

\begin{tabular}{lcc}
\hline \multicolumn{1}{c}{ Aspect } & Percentage & Criteria \\
\hline $\begin{array}{l}\text { The accuracy of } \\
\text { contents }\end{array}$ & $80 \%$ & Good \\
$\begin{array}{l}\text { The exactness of } \\
\text { content coverage }\end{array}$ & $80 \%$ & Good \\
$\begin{array}{l}\text { Digestibility } \\
\text { The use of language }\end{array}$ & $80 \%$ & Good \\
\hline
\end{tabular}

Analysis of the questionnaire assessment by design experts is viewed from 5 aspects: 1) Characteristics of RME, 2) Principle of RME, 3) Stages of RME, 4) Characteristics of Toondoo, and 5) Characteristics of Toondoo based on RME. The results of the validation can be seen in Table 5 .

Table 5. The assessment aspects of Toondoo online comic design experts

\begin{tabular}{lcc}
\hline \multicolumn{1}{c}{ Aspects } & Percentage & Criteria \\
\hline Characteristics of & $96 \%$ & Very \\
RME & & good \\
RME principle & $80 \%$ & good \\
RME stages & $82.85 \%$ & good \\
Characteristics of & $80 \%$ & good \\
Toondoo & & \\
Characteristics of & $86.67 \%$ & Very \\
RME-based Toondoo & & good \\
\hline
\end{tabular}

Validity data that is obtained from design experts were analyzed as a whole. The data is calculated by $\Sigma$ (answer x weight of each choice) is 111 , $\Sigma$ (many items of the questionnaire) is 25 with the highest weight is 5. Based on the calculation of the validity test that is the total score obtained from respondents divided by the ideal score of the assessment it can concluded that the percentage of validity from media experts is $88.8 \%$ with very valid qualifications.

Analysis of the questionnaire assessment by media experts is viewed from 8 aspects: 1) Whole display, 2) Simplicity, 3) Accuracy of content, 4) Emphasis, 5) Balance, 6) Form, 7) Texture and 8) Color. The results of the validation can be seen in Table 6 .

Table 6. The assessment aspects of Toondoo online comic media experts

\begin{tabular}{lcc}
\hline \multicolumn{1}{c}{ Aspect } & percentage & Criteria \\
\hline $\begin{array}{l}\text { Whole } \\
\text { display }\end{array}$ & $100 \%$ & Very good \\
simplicity & $95 \%$ & Very good \\
Accuracy of & $93.33 \%$ & Very good \\
content & & \\
Emphasis & $90 \%$ & Very good \\
Balance & $100 \%$ & Very good \\
Form & $88 \%$ & Very good \\
Texture & $100 \%$ & Very good \\
Color & $92 \%$ & Very good \\
\hline
\end{tabular}

Validity data that is obtained from media experts were analyzed as a whole. The data is calculated by $\Sigma$ (answer x weight of each choice) is 127 , $\Sigma$ (many items of the questionnaire) is 27 with the highest weight is 5. Based on the calculation of the validity test that is the total score obtained from respondents divided by the ideal score of the assessment it can concluded that the percentage of validity from media experts is $94.07 \%$ with very valid qualifications.

The three validity data from material experts, design experts and online comic media experts are calculated to be $87.62 \%$ in the very valid category.

\section{Analysis of Practicality Data}

To find out the practicality of Toondoo online comic media, an analysis of respondent questionnaires was given to subject teachers, students in small groups and students in large 
groups. Practicality data from the teacher assessment questionnaire calculated by $\Sigma$ (answer $\mathrm{x}$ weight of each choice) is 43, $\Sigma$ (many questionnaire items) is 12 with the highest weighting is 5. Based on practicality test calculations namely the total score obtained from the respondent divided by the ideal score assessment obtained the practicality percentage of subject teachers is $71.67 \%$ with practical qualifications.

Practicality data were also obtained from students' assessment of Toondoo online comic in a small group of 10 students. Many items of the questionnaire consisted of 13 statements with a maximum weighting of 5 . Based on practicality data calculations, which is $79.23 \%$ with practical criteria. Besides, practicality questionnaires are also given to students in large groups to assess online comic media Toondoo. This large group consists of 23 students; the number of questionnaire items is 13 statements with the highest weighting 5 . So that the practicality of comic media percentage obtained in large groups is $80.47 \%$ with very practical qualifications. To find out the practicality of Toondoo online comic media as a whole, it is taken on average from the subject teacher questionnaire assessment, student responses in small
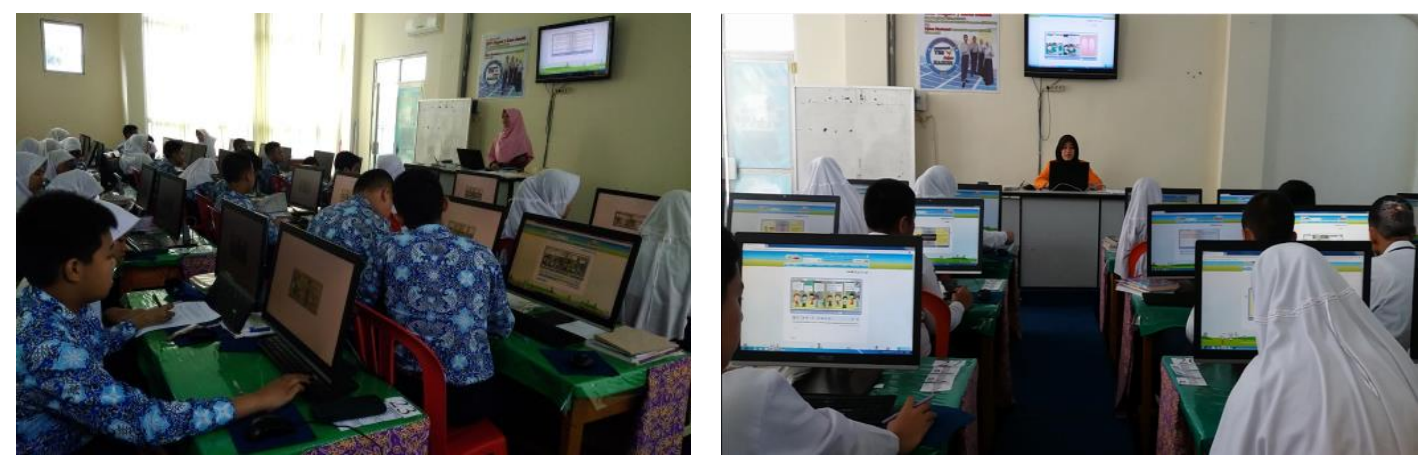

Figure 9. Learning process with the use of Toondoo online comic

groups and student responses in large groups, namely $77.12 \%$ with practical criteria.

This practicality is in accordance with research conducted by Wahyudin, Jepri, Simamora, Pratiwi, \& Rina (2020), the use of Toondoo in making comics can facilitate teacher in teaching. This is because Toondoo is supported by user friendly features and serves the purpose of the lesson.

\section{Analysis of Effectiveness Data}

The effectiveness data of Toondoo online comic media based on realistic math education is also seen through student learning achievement test on relations and functions material in class VIII SMP. The learning achievement test was attended by 34 students, which was held for 90 minutes and consisted of 20 multiple-choice questions. Out of 34 students who took the test, there were two students who did not meet the KKM (Minimum Mastery Criteria). This is due to the absence of those two students in several meetings of the lesson. Furthermore, based on students' learning achievement test, it is acquired that learning completion is classically $94.12 \%$ (very effective), in which the minimum mastery criteria is 75 .

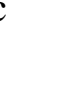


The Figure 9 shows learning process that used Toondoo online comic. The learning was held during 6 meetings in the computer laboratory of SMPN 7 Jambi. During the observation, students' interest towards comic that was read online can be identified clearly. They feel more relaxed and not monotonous, so it gives the impression that mathematics is not a stressful subject. Through comic dialog created based on the context of realistic math education, students construct meaningful knowledge from experiences in everyday life. After reading the comic, students are able to absorb and communicate the concept obtained from the comic. From the results of research observations, Toondoo online comic is effective when it is applied in learning mathematics in schools.

This is in accordance with research conducted by Subroto, Qohar, $\&$ Dwiyana (2020). The effectiveness of the use of comics in mathematics learning is caused comics containing many colors and images. And when transform learning materials into comics, the material will be easier because the material is delivered in the form of everyday conversation.

Research conducted by Suparman, Eliyanti, \& Hermawati (2020) also gave similar results. Presentation of material lesson using comic media gives a significant increase in learning outcomes. This increase in learning outcomes is also supported by an increase in students' interest in reading.

\section{Analysis of Mathematical Literacy Skills}

The aim of Toondoo online comic development is to provide encouragement to students' mathematical literacy skills. After Toondoo online comic learning process has been implemented on relations and functions material, students are asked to review the problems contained in the comic.

Students are very enthusiastic to communicate the results of their comic reading and explain some findings on the concept of relations and functions material from the dialog between characters in comic. Through comic media students will relax (not monotonous) and even feel they are not learning, so students are not stressful with the subject matter because the comic characteristics are presented in the story line (Danaswari, 2013). This is also accordance with, Danaswari (2013), and Toh \& Kaur (2019) that the presentation of mathematics in the form of comics can help children in accelerating reading, and can reduce children's boredom about mathematics because the visual association provided by educational comics supports understanding of abstract concepts better than long texts written in formal language.

Students can be categorized to have achieved literacy skills if they are at level 3 and above (Julie, Sanjaya, \& Anggoro, 2017; OECD, 2009). From the results of the work on the problems it is known that 31 of 34 students have achieved mathematical literacy skills with a percentage of $91.17 \%$ with very good criteria. There are 15 students who have reached level 5, 11 students have reached level 4, 5 students are at level 3, and 3 students are at level 2. Then the average grade of literacy is 595.25, which indicates that the students' literacy skills are at level 4. Therefore, it can be concluded that the average value of mathematical literacy of the class is able to reach above level 3 , 
through mathematics learning using Toondoo online comic based on realistic math education.

This implication is in accordance with the research of Nurkamilah, Nugraha, \& Sunendar (2018) where the main principle of RME in the comics developed emphasizes that mathematics is a human activity and mathematical material must be meaningful to students. This is a driving force for the learning stages to develop mathematical literacy.

The implication obtained from this research is the use of Toondoo in making comics can facilitate teacher in teaching. This is because Toondoo is supported by user friendly features and serves the purpose of the lesson. Besides that, students feel more relaxed and not monotonous when they learning mathematics. So it gives the impression that mathematics is not a stressful subject. Through comic dialog created based on the context of realistic math education, students construct meaningful knowledge from experiences in everyday life. Using comic to Presentation of material lesson gives a significant increase in learning outcomes. This is also supported by an increase in students' interest in reading. Through mathematics learning using Toondoo online comic based on realistic math education can increase average value of mathematical literacy of the class to reach above level 3 .

\section{CONCLUSION AND SUGGESTION}

Based on data analysis and research results, a very valid Toondoo online comic was obtained from material experts, design experts and media experts. Practical online comic was found from individual trials of subject teachers and student responses in small and large groups. The results of the learning achievement test of the VIII grade student SMPN 7 Jambi also showed that Toondoo online comic was very effective in the mathematics learning process. Therefore, it can be concluded that Toondoo online comic media based on realistic math education on relations and functions material in junior high school is very valid, practical and very effective so that it is feasible to be used in learning mathematics.

Suggestions that can be given by the researchers of Toondoo online comic media based on realistic math education are very effective to be implemented in learning mathematics and are highly recommended for teachers to develop comic media by means of Toondoo online application. Suggestion for future research is that to apply Toondoo online comic media for distance learning or indirect learning.

\section{REFERENCES}

Abidin, Y. (2017). Pembelajaran Literasi: Strategi Meningkatkan Kemampuan Literasi Matematika, Sains, Membaca, dan Menulis. Jakarta: Bumi Aksara.

Affeldt, F., Meinhart, D., \& Eilks, I. (2018). The Use of Comics in Experimental Instructions in a Non-formal Chemistry Learning Context. International Journal of Education in Mathematics, Science and Technology, 93-104. https://doi.org/10.18404/ijemst.380 620

Arsyad, A. (2014). Media Pembelajaran. Jakarta: PT. Raja Grafindo Persada.

Danaswari, R. (2013). Pengembangan Bahan Ajar dalam Bentuk Media Komik untuk Meningkatkan Hasil 
DOI: https://doi.org/10.24127/ajpm.v10i4.3875

Belajar Peserta Didik Kelas X SMAN 9 Cirebon pada Pokok Bahasan Ekosistem. Jurnal Scientiae Edumatica, 2(2), 1-17. Retrieved from http://id.portalgaruda.org/index.ph p?ref=browse \&mod=view .article \& article $=447159$

Febrianto, A., Kamid, \& Rohati. (2015). Desain Media Komik Matematika dengan Menggunakan Model Problem Based Learning (PBL) pada Materi Aritmetika Sosial di Kelas VII SMP Xaverius 2 Kota Jambi. EDUMATICA | Jurnal Pendidikan Matematika, 05, 1-8. https://doi.org/https://doi.org/10.22 437/edumatica.v5i02.2924

González, V., \& Milena, A. (2016). Comics Toondoo Collaborative Learning, a Visual Literasy Resaource to Evidence Vocabulary Learning with Emphasis in Actionverbs in an Efl, Group of Seventh Graders in a Cajicà School. Bagotá DC. Retrieved from

https://repository.usta.edu.co/bitstr eam/handle/11634/4351/Velandia Alba2017.pdf?isAllowed=y\&seque nce $=1$

Julie, C., \& Gierdien, F. (2020). Reflections on Realistic Mathematics Education from a South African Perspective. In Marja van den Heuvel-Panhuizen (Ed.), International Reflections on the Netherlands Didactics of Mathematics Visions on and Experiences with Realistic Mathematics Education (pp. 7182). Springer Open. https://doi.org/10.1007/978-3-03020223-1_5
Julie, H., Sanjaya, F., \& Anggoro, A. Y. (2017). The students' ability in the mathematical literacy for uncertainty problems on the PISA adaptation test. AIP Conference Proceedings, 1868, 050026. https://doi.org/10.1063/1.4995153

Mahdiansyah. (2014). Literasi Matematika Siswa Pendidikan Menengah: Analisis Menggunakan Desain Tes Internasional dengan Konteks Indonesoa. Jurnal Pendidikan, 4, 1-8.

Matuk, C., Hurwich, T., Spiegel, A., \& Diamond, J. (2021). How Do Teachers Use Comics to Promote Engagement, Equity, and Diversity in Science Classrooms? Research in Science Education, 51(3), 685732.

https://doi.org/10.1007/s11165018-9814-8

Mercat, C., Vennebush, P., Budd, C., Simões, C., \& Struckmeier, J. (2017). Topic Study Group No. 07: Popularization of Mathematics. https://doi.org/10.1007/978-3-31962597-3_34

Nurkamilah, M., Nugraha, M. F., \& Sunendar, A. (2018). Mengembangkan Literasi Matematika Siswa Sekolah Dasar melalui Pembelajaran Matematika Realistik Indonesia. Jurnal Theorems (The Original Research of Mathematics), 2(2), 70-79. https://doi.org/http://dx.doi.org/10. 31949/th.v2i2.722

OECD. (2009). Learning Mathematiccs for Life: a View Perspective From PISA.

OECD. (2019). OECD. (2019). PISA 2018 insights and interpretations. 
DOI: https://doi.org/10.24127/ajpm.v10i4.3875

OECD Publishing, 64 https://www.oecd.org/pisa/PISA 2018 Insights and Interpretations FINAL PDF.pdfPISA 2018 insights and interpretations. $O E C D$ Publishing.

Ojose, B. (2011). Mathematics literacy: are we able to put the mathematics we learn into everyday use? Journal of Mathematics Education.

Peck, F. A. (2018). Rejecting platonism: Recovering humanity in mathematics education. Education Sciences, $8(2)$. https://doi.org/10.3390/educsci802 0043

Printina, B. I. (2017). Penggunaan Sumber Belajar Digital Exelsa Moodle dan Komik Toondo Dalam Meningkatkan Kreativitas Belajar Sejarah. AGASTYA: Jurnal Ssejarah Dan Pembelajarannya, 7(2), 57. https://doi.org/10.25273/ajsp.v7i2. 1489

Rohati, Winarni, S., \& Hidayat, R. (2018). Pengembangan Media Pembelajaran Komik Matematika Berbasis Problem Based Learning dengan Manga Studio V05 dan Geogebra. EDUMATICA | Jurnal Pendidikan Matematika, 8(2), 8191.

https://doi.org/10.22437/edumatica .v8i2.5486

Sanjaya, W. (2014). Media Komunikasi Pembelajaran. Jakarta: Prenadamedia Group.

Spiegel, A. N., McQuillan, J., Halpin, P., Matuk, C., \& Diamond, J. (2013). Engaging Teenagers with Science Through Comics. Research in Science Education,
43(6), 2309-2326. https://doi.org/10.1007/s11165013-9358-x

Subroto, E. N., Qohar, A., \& Dwiyana, D. (2020). Efektivitas Pemanfaatan Komik sebagai Media Pembelajaran Matematika. Jurnal Pendidikan: Teori, Penelitian, Dan Pengembangan, 5(2), 135. https://doi.org/10.17977/jptpp.v5i2 .13156

Sumantri, M. (2015). Strategi Pembelajaran Teori dan Praktik Pendidikan Dasar. Jakarta: PT. Raja Grafindo Persada.

Suparman, I. W., Eliyanti, M., \& Hermawati, E. (2020). Pengaruh Penyajian Materi dalam Bentuk Media Komik terhadap Minat Baca dan Hasil Belajar. Pedagogi: Jurnal Penelitian Pendidikan, 7(1). https://doi.org/10.25134/pedagogi. v7i1.2860

Theodora, F. R. N., \& Hidayat, D. (2018). the Use of Realistic Mathematics Education in Teaching the Concept of Equality. JOHME: Journal of Holistic Mathematics Education, 1(2), 104. https://doi.org/10.19166/johme.v1i 2.913

Toh, T. L., \& Kaur, B. (2019). Low Attainers and Learning of Mathematics.

https://doi.org/10.1007/978-98113-3573-0_13

Wahyudin, A. Y., Jepri, D., Simamora, M. W., Pratiwi, I. W., \& Rina, A. (2020). Penggunaan Komik Digital Toondoo dalam Pembelajaran Bahasa Inggris Tingkat Sekolah Menengah. Journal of Social Sciences and Technology for 
DOI: https://doi.org/10.24127/ajpm.v10i4.3875

Community Service (JSSTCS), $1(1), \quad 1$. https://doi.org/10.33365/jta.v1i1.67 3

Webb, D. C., \& Peck, F. A. (2020). From Tinkering to Practice-The Role of Teachers in the Application of Realistic Mathematics Education Principles in the United States. In M. van den Heuvel-Panhuizen (Ed.), International Reflections on the Netherlands Didactics ofMathematics, ICME-13 Monographs (pp. 21-39). Springer International Publishing. https://doi.org/10.1007/978-3-03020223-1_2

Widari, I. G. A. A., Putra, I. G. N. N., \& Suwijaya, I. K. (2013). Penerapan Pendekatan Pembelajaran Matematika Realistik Sebagai Upaya Meningkatkan Aktivitas dan Prestasi Belajar Siswa dalam Pembelajaran Bangun Ruang pada Siswa Kelas IPA SDN 9 Sesetan Tahun Pelajaran 2011/2012. Jurnal Santiaji Pendidikan (JSP), 3(2), 189-212. Retrieved from https://jurnal.unmas.ac.id/index.ph $\mathrm{p} / \mathrm{JSP} /$ article/view/20

Widjaja, W. (2013). The Use of Contextual Problems to Support Mathematical Learning. Journal on Mathematics Education, 4(2). https://doi.org/10.22342/jme.4.2.41 3.151-159

Widyastuti, P. D., Rasiman, \& Setyowati, R. D. (2016). Pengembangan Media Pembelajaran Berbasis Komik Online Toondoo dengan Metode Diskusi dan Tanya Jawab untuk Materi Geometri Datar pada Siswa Kelas X di SMA Negeri 5 Semarang. Prosiding Seminar Matematika Dan Pendiidkan Matematika.

Wijaya, A. (2012). Pendidikan Matematika Realistik Suatu Alternatif Pendekatan Pembelajaran Matematika. In Graha ilmu.

Wilujeng, N. (2015). Komik Daring (Alternatif Pengajaran Keterampilan Menulis bagi Mahasiswa Jurusan Pendidikan Bahasa Prancis). Yogyakarta: Universitas Negeri Yogyakarta.

Yuanita, P., Zulnaidi, H., \& Zakaria, E. (2018). The effectiveness of Realistic Mathematics Education approach: The role of mathematical representation as mediator between mathematical belief and problem solving. PLOS ONE, 13(9), e0204847. https://doi.org/10.1371/journal.pon e.0204847 